\title{
Gordon Tullock: economic gadfly
}

\author{
Dennis C. Mueller ${ }^{1}$
}

(c) The Author(s) 2016. This article is published with open access at Springerlink.com

\begin{abstract}
This article discusses Gordon Tullock's impact on the economics profession and on public choice in particular. It measures this impact through his publications, his editorship of the journal Public Choice, and his association with the Center for Public Choice.
\end{abstract}

Keywords Public choice $\cdot$ Rent seeking

JEL Classification D70 $\cdot$ D72

Gordon Tullock may have been the brightest person I ever met. I say "may have," because some brilliant people can also be quite reticent, so that their brilliance does not immediately shine forth. This certainly was not the case with Gordon Tullock. Upon first meeting a young Gordon Tullock, one would immediately be peppered with a stream of questions testing one's economic knowledge. If one succeeded in disposing of one question, Tullock moved quickly on to another. There seemed to be no topic in economics, and many topics outside of economics, on which he could not hold forth. To engage him in conversation over lunch was to participate in an intellectual roller coaster. As Gordon Tullock aged, he began to slow down a bit and became less combative. In his prime, however, the quickness of his mind was both readily apparent and a bit overwhelming.

Dennis C. Mueller

dennis.mueller@univie.ac.at

1 University of Vienna, Vienna, Austria 
One of the definitions of gadfly in my American Heritage Dictionary reads (1967), "One who acts as a constructively provocative stimulus." "Provocative stimulus" is an apt characterization of Gordon Tullock, although one might argue that his stimuli were not always very constructive. I was asked to write about Tullock's "impulse to the field." In thinking about this topic, it occurred to me that Tullock's impulses were often not direct consequences of the logical arguments in one of his publications, but were a result of the provocative stimuli coming forth from him both through direct contact and on the printed page. This explains my choice for a title of this essay. It also explains why I do not exclusively focus on the impact of his research on the profession. The next section does, however, deal with this topic. The essay goes on the discuss Tullock's impacts via the Center for the Study of Public Choice (Sect. 2), the Public Choice journal (Sect. 3). Some final thoughts bring the essay to a conclusion.

\section{The impact of Tullock's publications}

How does one measure the influence of a scholar on the profession, and more generally on the evolution of ideas in the areas of the scholar's interests? This question is particularly difficult to answer in the case of Gordon Tullock, since he wrote on such a wide variety of topics. Trained in law, he has many publications in this field. His Trials on Trial (1980a) won the first Leslie T. Wilkins Award from the Criminal Justice and Research Center in 1982, as an outstanding contribution to the fields of criminology and criminal justice. In 1992, he was awarded an Honorary Doctorate of Law by the University of Chicago. His impact on the fields of law and criminology appears to have been significant, but I am not knowledgeable enough in these areas to say very much. He became interested in social biology, and has several publications on this topic. Even his work in economics spans a broad spectrum-his first publication was a Journal of Political Economy article on hyperinflation in China (Campbell and Tullock 1954). His most significant contributions have been in the field of public choice, and here again the range of topics is wide-voting rules, representative government, federalism, bureaucracy, revolution-to name but a few of the most important areas in which Tullock worked. One can also list him as an important figure in political science. In 1996, he was elected a Member of the American Political Science Review Hall of Fame.

The sheer volume of Gordon Tullock's publications is astounding-20 some books and monographs authored or coauthored, 15 books edited or co-edited. The section of his curriculum vitae devoted to articles published in journals runs to 25 pages. Many of these articles were selected for republication by editors of collected volumes. Here again one must remark not only on the length of Tullock's publication list, but also on its breadth. Durden et al. (1991, pp. 192-93) list 125 scientific journals, which cited Tullock's publications as reported in the Social Science Citation Index as of 1991, and report that another 308 journals have at least one citation of his work. They identify $55.4 \%$ of Tullock's research falling into the general area of economics, $11.3 \%$ in law, $10 \%$ in political science, $2.1 \%$ in 
business and finance, and an astounding $21.2 \%$ falling in still other fields like social biology.

Tullock's first major contribution to the public choice literature, "Problems of Majority Voting," (1959), for example, was republished four times, including in the prestigious American Economics Association volume edited by Kenneth Arrow and Tibor Scitovsky (1969), Readings in Welfare Economics. "The Welfare Costs of Tariffs, Monopolies and Theft" (Tullock 1967c) was republished five times including in one volume in which Tullock was a co-editor. These re-publications in volumes edited by a large number of different scholars, some highly distinguished, is certainly one form of recognition by the profession.

Another way to judge the impact of a scholar on the field is to see how often her or his research is cited by other scholars. Accessing Google Scholar on March 3, 2015, I found 19,200 entries under the name of Gordon Tullock. The 15 publications (not including edited volumes) cited the most were as follows ${ }^{1}$ :

1. The Calculus of Consent (1962) hardback and paperback editions, written with James M. Buchanan, 9345 citations.

2. "The Welfare Costs of Tariffs, Monopolies and Theft" (Tullock 1967c), reprinted four times in volumes edited by others, 3411 citations.

3. "Efficient Rent Seeking" (Tullock 1980b), 2469 citations.

4. “An Empirical Analysis of Cross-National Economic Growth" (1989), written with Kevin B. Grier, 1163 citations.

5. The Politics of Bureaucracy (Tullock 1965), 1556 citations.

6. "Polluters' Profits and Political Response: Direct Controls Versus Taxes," (1975), written with James M. Buchanan, reprinted once, 812 citations.

7. Toward a Mathematics of Politics (Tullock 1967a), 727 citations.

8. "Problems of Majority Voting," (Tullock 1959), 503 citations.

9. “The Paradox of Revolution," (Tullock 1971), reprinted once, 425 citations.

10. Autocracy (Tullock 1987), 416 citations.

11. "A New and Superior Process for Making Social Choices," (1976), written with T. Niclaus Tideman, reprinted three times, 373 citations.

12. The Economics of Special Privilege and Rent Seeking (Tullock 1989), 372 citations.

13. "Why So Much Stability?" (Tullock 1981), reprinted twice, 358 citations.

14. The Vote Motive (Tullock 1976), 341 citations.

15. Rent Seeking (Tullock 1993), 327 citations.

In total, I counted almost 50 publications with a hundred or more citations. I find this a fairly impressive record. Many articles, even in prestigious journals, receive only a handful of citations. Some appear to have been read only by the journal's referees. Tullock's work has clearly attracted considerable attention from other scholars.

\footnotetext{
${ }^{1}$ Durden et al. (1991) present a much longer list of Tullock's publications along with the numbers of citations in the Social Science Citation Index as of 1991.
} 
So I conclude that Gordon Tullock's impact on the profession, or better said the professions given his broad range of research topics, has been immense. Let me now play the role of curmudgeon and say that his impact could have been still greater had he devoted a bit more time formulating some of his ideas. One has the impression sometimes that he wrote as fast as he talked resulting in some of his publications failing to attract the attention that they might have.

Evidence in support of this assertion might be found by comparing Tullock's success with that of a few of the other founding fathers of public choice. Where Tullock wrote quickly and published an immense body of research, Mancur Olson's reputation rests on two or three books and a handful of seminal articles. Olson took great care in crafting his arguments, and thus his second major work, The Rise and Decline of Nations, appeared 17 years after his first major publication, The Logic of Collective Action (Olson 1965, 1982). Google Scholar reports 30,400 results for Olson. The Logic registered 28,785 citations, The Rise and Decline of Nations 8595, about the same number as The Calculus of Consent. Anthony Downs recorded 74,000 results in Google Scholar. His classic, An Economic Theory of Democracy, had 22,726 citations (Downs 1957). I would also list Kenneth Arrow as one of the founding fathers of public choice. His Social Choice and Individual Values had 14,888 citations (Arrow 1951, 1963). Interestingly, three of these classics-Olson's Logic of Collective Action and the books by Downs and Arrow-were their doctoral dissertations, works upon which each author presumably devoted a lot of time and effort.

Further support for the point I am making arises when one looks at the history of Tullock's most cited work after The Calculus - "The Welfare Costs of Tariffs, Monopolies and Theft" (Tullock 1967c). The significance of this piece did not occur to me, however, until I read Anne Krueger's (1974) American Economic Review article in 1974, where the term "rent seeking" first appears. As I read Krueger's article, I had a sense of deja $v u$ and then it dawned on me that I had seen Krueger's rent-seeking analysis in Tullock's 1967 article. As noted above, Tullock's original rent-seeking paper received 3411 citations. Krueger's AER article, on the other hand, was cited 5864 times. In the 100 pages of citations to Tullock's “The Welfare Costs of Tariffs, Monopolies and Theft" in Google Scholar, I was able to identify only five that preceded 1974. It appears that most of the profession, like I, did not appreciate the importance of Tullock's contribution until after they read Krueger's article. One explanation for this is probably that the article first appeared in the Western Economic Journal (now Economic Inquiry), not regarded as a top journal in 1967. Brady and Tollison (1991, p. 145) mention that the article was rejected by the American Economic Review, Economica, and the Southern Economic Journal before being accepted at the Western Economic Journal. Tullock (2003, p. 5) stated that it was also rejected by the Journal of Political Economy. John Gurley, editor of the American Economic Review in 1966, gave this explanation for his decision, "You will no doubt note that the referee neglects your point regarding the amount of real resources devoted to establishing, promoting, destroying, etc., monopolies. However, I have noted it, and, while I think it is certainly valid, it does not appear significant enough (as a theoretical contribution) to overthrow the referee's recommendation" (Brady and Tollison 1991, p. 146). The 
referee misses the rent-seeking argument entirely, the editor recognizes it, but fails to see its importance. Another example of an obtuse referee and a callous journal editor, perhaps, but one might also argue that the paper might have enjoyed a better fate, if Tullock had taken a bit more care in crafting the arguments. How many additional citations would "The Welfare Costs of Tariffs, Monopolies and Theft" have received, if it had first appeared in the American Economic Review?

Another instance of Tullock's work having less impact than it should have had is the fate of his "The General Irrelevance of the General Impossibility Theorem," (Tullock 1967b). This paper demonstrated with a tortuous application of geometry that the area of the issue space in which cycling would occur shrinks as the number of voters increases. Arrow's celebrated impossibility result sinks into irrelevance as the size of the electorate expands. Tullock delivered the coup de grace to one of the most important contributions to the literature. Despite being published in one of the most prestigious economic journals, The Quarterly Journal of Economics, and despite its provocative title, the article did not spell the end to the literature devoted to the Arrow cycling problem. It records a respectable 227 citations in Google Scholar, but it is difficult to say that it changed the trajectory of the public choice literature. It is also worth noting that it anticipated the discovery of the uncovered set more than a decade later. ${ }^{2}$

Let me conclude this discussion of the impact of Tullock's published research by repeating that its impact was significant. If I am correct, however, its impact could have been even greater had Tullock devoted a little more time and care to expressing his arguments.

\section{The Center for the Study of Public Choice}

In the 1960s, James Buchanan and Gordon Tullock were at the Thomas Jefferson Center for Political Economy at the University of Virginia. They both exited from the University of Virginia at the end of the 1960s and soon regrouped at the Virginia Polytechnic Institute and State University (VPI) in Blacksburg, Virginia. There they founded The Center for the Study of Public Choice. The Center occupied a charming old mansion on a hill in the center of the VPI campus.

In 1985 James Buchanan started an annual lecture series to which people from around the Washington area were invited and treated to a hopefully interesting lecture, cocktails, and a banquet. I was asked to give the first lecture and entitled it "The Virginia School," picking up a name Mancur Olson coined to describe the work of Buchanan, Tullock, and their followers (Mueller 1993). In it I made the point that it is important for the spreading of the ideas of a particular school-the Chicago school, the Cambridge (England) school-for the leaders of the school of thought to be located at a particular location, so that scholars interested in learning about their ideas can visit them. That is why, I argued, it was legitimate to talk about Chicago and Cambridge schools of thought, but not a Marxist school, since there was no place at which a distinguished group of Marxist scholars was gathered.

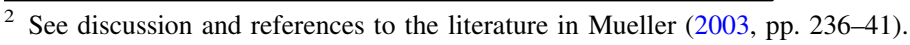


The existence of the Center for the Study of Public Choice made it legitimate to think of there being a "Virginia School" of thought. The Center soon became a Mecca for scholars interested in the fairly young field of public choice. Its list of visitors is both long and contains many prominent scholars, or at least people who would later become prominent scholars. For example, during the spring of 1973, when I was a post-doctoral fellow at the center, the Nobel Prize winner James Meade and his wife visited for 3 months.

Three other early visitors from Europe were Elisabeth Liefmann-Keil, Bruno Frey, and Peter Bernholz. They soon founded the European Public Choice Society. Elisabeth Liefmann-Keil was the society's first president, 1972-74, and she was followed as president by Peter Bernholz, 1974-81. As with its American counterpart, the European Public Choice Society began with meetings of no more than 20 or so participants. Today it is a thriving society with annual meetings attracting 350 or more participants-more than its American counterpart is able to attract at this time. A somewhat similar story explains the creation of the Japanese Public Choice Society by Professor Hiroshi Kato following a visit to the Public Choice Center in Blacksburg. ${ }^{3}$

With the help of Geoffrey Brennan, Roger Congleton and Robert Tollison, I have tried to put together a list of important visitors to the Center in both Blacksburg and Fairfax, to which the Center moved in the early 1980s. By visitor to the Center I mean someone who spent a period of time in residence there, not someone who only came and held a seminar and then immediately departed. The list is undoubtedly incomplete and I apologize to those persons I have omitted. It is nevertheless rather long and impressive (see Table 1).

The sheer number of visitors to the Public Choice Center over the years is astounding. Also noteworthy is the fact that an overwhelming majority of the visitors came from outside of the United States. They also possessed a diversity of professional interests-economics, philosophy, political science, sociology, sociobiology, and of course, public choice. This diversity made the Public Choice Center a very interesting, indeed exciting, place to visit.

Of course, all of these visitors did not come to the Public Choice Center simply because Gordon Tullock was there. In addition to Buchanan and Tullock, the Center has always contained several additional members, both senior and junior, working in public choice. Some of these, like Geoffrey Brennan, Roger Congleton and Robert Tollison, have become distinguished scholars in their own rights. But, particularly at its beginning, the incentive to visit the Public Choice Center would have mostly been to rub elbows with Buchanan and Tullock.

What effect did they, and in particular Gordon Tullock, have on the visitors to the Center? Can we observe epiphanies in some visitors to the Public Choice Center? If so, was it James Buchanan or Gordon Tullock, or perhaps both together, who caused the transformations? I assume that the answers to these questions is in some cases "yes," and that one might be able to identify the persons whose research paths were altered by a visit to the Center either by a careful examination of their research, or

\footnotetext{
${ }^{3}$ See, discussion by Professor Akihito Udagawa, who was also greatly influenced by his visit to the Center. http://publicchoice.info/Buchanan/files/udagawa.htm, accessed Dec. 3, 2013.
} 
Table 1 Visitors to The Center for the Study of Public Choice

\begin{tabular}{|c|c|c|}
\hline 1. Kuniomi Akagi & 71. Samuel Hollander & 141. Werner Pommerehne \\
\hline 2. Coskun Can Aktan & 72. James L. Hudson & 142. David A. Reese \\
\hline 3. Hans Albert & 73. Robert Hughes & 143. David Reisman \\
\hline 4. Max Albert & 74. Brooks Hull & 144. Pill-Woo Rhee \\
\hline 5. Robert Albon & 75. Lester Hunt & 145. Rudolf Richter \\
\hline 6. Gary Anderson & 76. William J. Hunter & 146. Il-Seop Rim \\
\hline 7. Bunshiro Ando & 77. Hirokuni Iijma & 147. Jennifer Ruback \\
\hline 8. Thomas Apolte & 78. Anthony de Jasay & 148. Carlos Sabino \\
\hline 9. Omer Arasil & 79. Bruno Jeitziner & 149. Andras Sajo \\
\hline 10. Detlef Auf der Heide & 80. Ali Kahn & 150. Kenichi Sakakibara \\
\hline 11. Hakan Ay & 81. Hiroyuki Kawanobe & 151. Mustafa Sakal \\
\hline 12. George Ayittey & 82. Chung-Ho Kim & 152. Javier Salinas \\
\hline 13. Jordi Bacaria & 83. Gebhard Kirchgässner & 153. Pierre Salmon \\
\hline 14. Rina Battiato & 84. Hartmut Kliemt & 154. Vural Savas \\
\hline 15. Salvatore Enrico Battiato & 85. Barbara Krug & 155. David Schap \\
\hline 16. Sebastiano Bavetta & 86. Hitoshi Kugenuma & 156. Allan Schmid \\
\hline 17. Ingemar Bengtsson & 87. Kazuyoshi Kurokawa & 157. Dieter Schmidtchen \\
\hline 18. R. J. Bennett & 88. David Laband & 158. Friedrich Schneider \\
\hline 19. Uri Ben-Zion & 89. Sanghack Lee & 159. Marten Schultz \\
\hline 20. Beat Blankart & 90. Martin Leschke & 160. Noboru Sekiya \\
\hline 21. Gordon Brady & 91. Shirley Letwin & 161. Arthur Seldon \\
\hline 22. Royall Brandis & 92. Peter Lewisch & 162. Roger Sherman \\
\hline 23. Charles H. Breeden & 93. Hans-Edi Loef & 163. Francisco Garcia Sobrecases \\
\hline 24. Penelope J. Brook & 94. Loren Lomasky & 164. Karol Soltan \\
\hline 25. Pamela Brown & 95. Fernando Toboso Lopez & 165. Birgir Thor Solvanson \\
\hline 26. Eugenio Cerioni & 96. Uskali Maki & 166. Uriel Spiegel \\
\hline 27. Oh-Hyun Chang & 97. Chrysoshomos Mantzavinos & 167. Bernard Steunenberg \\
\hline 28. Young Back Choi & 98. Jacob Markl & 168. M. H. Tamaddon-Jahromi \\
\hline 29. Dennis Coates & 99. Edward Lopez & 169. Kiyokazu Tanaka \\
\hline 30. James Coleman & 100. Elizabetta Marmolo & 170. Sabri Tekir \\
\hline 31. Peter Coughlin & 101. Paolo Martelli & 171. Hiromi Teramoto \\
\hline 32. Dennis Coyle & 102. John M. Mbaku & 172. Manfred Tietzel \\
\hline 33. Michael A. Crew & 103. Richard McKenzie & 173. Eugenia Toma \\
\hline 34. Bibekanada Das & 104. Nimai Mehta & 174. Mark Toma \\
\hline 35. William R. Dougan & 105. Antonio Menduina & 175. Jan Tumlir \\
\hline 36. Isaac Ehrlich & 106. William Mitchell & 176. Akihito Udagawa \\
\hline 37. Jon Elster & 107. Juan D. Montoro-Pons & 177. Lazlo Urban \\
\hline 38. Ross Emmett & 108. Hans Monissen & 178. Viktor Vanberg \\
\hline 39. Domenico da Empoli & 109. Peter Moser & 179. Martin van Hees \\
\hline 40. Dominik H. Enste & 110. Giafranco Mossetto & 180. Ulrich Van Lith \\
\hline 41. Giuseppe Eusepi & 111. Dennis C. Mueller & 181. Andrea Villani \\
\hline 42. Roger L. Faith & 112. Shigeto Naka & 182. Stefan Voigt \\
\hline 43. David I. Fand & 113. Manfred Neumann & 183. Thomas Voss \\
\hline
\end{tabular}


Table 1 continued

\begin{tabular}{|c|c|c|}
\hline 44. Mary Farmer & 114. Yew-Kwang Ng & 184. Karl Warneryd \\
\hline 45. Susan K. Feigenbaum & 115. Douglass North & 185. Hannelore Weck-Hannemann \\
\hline 46. Mariateresa Fiocca & 116. Robert Nozick & 186. Wolfgang Weigel \\
\hline 47. Arthur A. Fleisher III & 117. Rustem N. Nureev & 187. Edwin West \\
\hline 48. Anthony Flew & 118. Jiro Obata & 188. Jack Wiseman \\
\hline 49. Cay Folkers & 119. Yojiro Oiva & 189. Ulrich Witt \\
\hline 50. Francesco Forte & 120. Katsuyoshi Okui & 190. Weiyun Xu \\
\hline 51. Paul Foss & 121. Mancur Olson & 191. Mayumi Yamamoto \\
\hline 52. Pedro Puy Fraga & 122. Elinor Ostrom & 192. Attila Yayla \\
\hline 53. Paul Fudulu & 123. Vincent Ostrom & 193. Akira Yokoyama \\
\hline 54. Juan Carlos Gamazo & 124. Koshiro Ota & 194. Tatsuo Yoshida \\
\hline 55. Richard Gamble & 125. Taro Ozawa & 195. Jesus M. Zaratiegui \\
\hline 56. Otto Gandenberger & 126. Fabio Padovano & \\
\hline 57. Enrique Garcia-Ayavirl & 127. Karl-Heinz Paque & \\
\hline 58. Ernst Gellner & 128. Jose Casa Pardo & \\
\hline 59. Vladimir Gligorov & 129. Min Jeong Park & \\
\hline 60. Brian L. Goff & 130. Glenn Parker & \\
\hline 61. David Gow & 131. Ross Parrish & \\
\hline 62. Christa Gruenwald & 132. John Passmore & \\
\hline 63. Anand Gupta & 133. Sandra Peart & \\
\hline 64. Alan Hamlin & 134. Laura Pennacchi & \\
\hline 65. Bernd Hansjurgens & 135. Hartmut Picht & \\
\hline 66. Hiroo Harada & 136. Alberto di Pierro & \\
\hline 67. Ann Harper-Fender & 137. Ingo Pies & \\
\hline 68. Jac Heckelman & 138. Jonathan Pincus & \\
\hline 69. David Henderson & 139. Yakir Plessner & \\
\hline 70. Arye Hillman & 140. Charles Plott & \\
\hline
\end{tabular}

Some of these visitors took part in the week-long Liberty Fund workshops that were held at the Center during the summers in the early years

by extensive interviews. I have not conducted either. But given his personality and mode of conduct, any visitor to the Center for even one week would have had to interact with Gordon Tullock. Some of these interactions undoubtedly left some visitors angry or repulsed. Some visitors must have felt overwhelmed, and some almost certainly left with an altered perspective on the field of public choice and some different ideas about where their research should be directed.

\section{The Public Choice journal}

In the 1960s, while James Buchanan and Gordon Tullock were at the Thomas Jefferson Center for Political Economy at the University of Virginia. They organized a meeting of a small group of the pioneers working in what at that time 
was a novel area of research-the application of the methodology of economics to the study of political institutions. The papers presented at that meeting were published by the Thomas Jefferson Center in 1966 under the title, Papers on NonMarket Decision Making with Gordon Tullock as the editor.

Upon returning to Virginia, Buchanan and Tullock not only established The Center for the Study of Public Choice at VPI, they also founded a new journal to replace Papers on Non-Market Decision Making. Since Gordon Tullock had edited its predecessor, I suppose it was natural that he should edit the new journal, Public Choice. I also suspect that Buchanan did not wish to take on the time-consuming task of editing a journal.

Gordon Tullock was the editor of Public Choice until 1991, 25 years if one counts Papers on Non-Market Decision Making as the journal's forerunner. At least during the initial years of the journal's existence, Tullock appears to have been not only the only editor of Public Choice, but also its sole referee. One would submit a paper, and within a week receive an editorial decision from Gordon Tullock. If the paper was accepted for publication, it was typically accepted without a request for revisions. Ah, those were the days!

During the early years of the Public Choice journal's existence, it was one of the few journals that was receptive to this line of research. Since Tullock essentially decided what articles would appear in the journal, he can be said to have had a significant impact on the field's development through his editorship of the journal. Brady and Tollison (1991, p. 146) observe that Tullock as editor of Public Choice "took chances, he printed controversial papers, he was interested in ideas, and he depended on competition among scientists to straighten things out in the long run. This editorial policy... resulted in a number of important advances in economic theory and public choice..." Durden et al. (1991) assess the impact of the Public Choice journal under Tullock's (1966) editorship, and list the most important articles published in it while he was editor.

Gordon Tullock, as editor of Public Choice, was not adverse to publishing his own work in the journal. Sometimes these contributions might have been aptly subtitled, "ruminations on an interesting question in public choice." One such rumination was "Why So Much Stability?" (Tullock 1981). The problem of cycling under the simple majority rule has been a central issue in public choice from its very beginning when Arrow published his famous impossibility theorem. Indeed, if one counts Condorcet as the founder of public choice, it has been around for more than 200 years. The literature is replete with proofs of theorems showing that equilibria using the simple majority rule are extremely unlikely. Yet legislatures do not seem to go around in circles when they make decisions using the simple majority rule. Why not? This was the question posed by Tullock in this somewhat provocative article. One of the answers to the question was given by Tullock himself in 1967 as discussed above (Tullock 1967b). Tullock begins by reiterating the argument of his earlier contribution, but then goes on to offer still other possible answers in this 1981 article, mostly having to do with the stability of logrolling coalitions. The importance of this article for the development of public choice is not so much the answers Tullock gave to the question of stability, but its posing of the question itself. Numerous articles and books have appeared since 1981, which have wrestled 
with this question. ${ }^{4}$ Two articles appeared in Public Choice, which offered alternative theoretical explanations for the question posed by Tullock (Niemi 1983; Hill 1985), and a third presented an empirical test for the existence of cyclical majorities (Stratmann 1996). "Why So Much Stability?" is Tullock's thirteenth most cited work, 358 times according to Google Scholar. Here, as so often in his career, Gordon Tullock opened up a very important, one might say controversial line of research.

In "Efficient Rent Seeking” (Tullock 1980b), Tullock introduced a formula for calculating the probability of a participant's success in a rent-seeking contest. This formula became the workhorse for modelers of rent seeking, which explains why this article is the third most frequently cited publication of Gordon Tullock. Tullock also discussed problems of equilibria in rent-seeking contests in this article, and this too motivated future research. Two articles directly stimulated by this article appeared in a mini-symposium on efficient rent seeking published 5 years later in Public Choice (Corcoran and Karels 1985; Higgins et al. 1985). Tullock again used his prerogative as editor to make a small contribution to the debate, in which he described the literature on efficient rent seeking as a bog out of which scholars like those just mentioned and Tullock himself were struggling to emerge (Tullock 1985). He closed his short contribution with the observation that his "role in this controversy is to watch people trying to get out of the swamp and then push them back in" (Tullock 1985, p. 262). As with his ruminations about the stability of political outcomes, Tullock's thoughts concerning the efficiency and equilibria of rent-seeking contests are more interesting for the work they provoked than for the answers Tullock reached.

Resuming my role of curmudgeon, I again would say that these interjections into Public Choice, which certainly stimulated others to think and write about the issues raised, might well have had an even greater impact had Tullock devoted a bit more time to developing his arguments. "Why So Much Stability," for example, is a 13 page article without any divisions into sections dealing with specific topics and questions. It is more or less a stream of insightful consciousness. In the end, Tullock summarizes his theoretical explanation for why there is so much stability with the statement that "the stable outcomes that are observed...represent equilibria because the conditions needed to produce motion from some initial or intermediate positions appear to be more severe than has been generally assumed" (Tullock 1981). This answer to the stability question has, to my knowledge, not been adopted by most of the profession.

\section{Final thoughts}

There is a word in German that is used to describe something or some person as extremely unique-einmalig. I can think of no better word to use to characterize Gordon Tullock. Anyone who spent even a few hours with Gordon Tullock probably has never forgotten the experience. I was fortunate enough early in my

\footnotetext{
${ }^{4}$ See, for example, Mueller (2003, pp. 114-26).
} 
career to have spent a full year in his presence, and down through the years to have crossed paths, and sometimes swords with him many times. Although it is difficult to pinpoint turning points in my research as a result of conversations with Gordon Tullock, these conversations certainly affected the way I looked at questions in public choice.

While she was still alive I, and I think many other economists, expected that Joan Robinson would be the first woman to win a Nobel Prize in economics. The fact that she did not receive a Nobel Prize is probably explained by fear on the part of members of the committee that decides on the prizes that she would do something outlandish to embarrass the committee, when the prize was announced or in Stockholm at the awards ceremony. In her later years, Joan Robinson was anything but politically correct.

I suspect that a similar explanation accounts for Gordon Tullock not receiving the Nobel Prize. The prize is supposed to be awarded for particularly important and original contributions to economics. Typing the words "rent seeking" into Google Scholar on March 26, 2015 brought up "about 673,000 results." The concept of rent seeking has to be regarded as one of the most significant developments in economics over the last half century. Thus, the introduction of the concept of rent seeking would seem to warrant a Nobel Prize. Gordon Tullock, gadfly, maverick, enfant terrible, was probably too politically incorrect, even in his more mellow later years, for the Nobel Prize committee to risk awarding him the prize. The Nobel Prize committee would appear to have been of the view that Gordon Tullock was too einmalig.

Open Access This article is distributed under the terms of the Creative Commons Attribution 4.0 International License (http://creativecommons.org/licenses/by/4.0/), which permits unrestricted use, distribution, and reproduction in any medium, provided you give appropriate credit to the original author(s) and the source, provide a link to the Creative Commons license, and indicate if changes were made.

\section{References}

Arrow, K. J. (1951). Social choice and individual values, New York: Wiley, rev. ed. 1963.

Arrow, K. J., \& Scitovsky, T. (Eds.). (1969). Readings in welfare economics. Homewood, IL: Richard D. Irwin.

Brady, G. L., \& Tollison, R. D. (1991). Gordon Tullock: Creative maverick of public choice. Public Choice, 71, 141-148.

Buchanan, J. M., \& Tullock, G. (1962). The calculus of consent. Ann Arbor, MI: University of Michigan Press.

Buchanan, J. M., \& Tullock, G. (1975). Polluters profits and political response: Direct controls versus taxes. American Economic Review, 65, 139-147.

Campbell, C., \& Tullock, G. (1954). Hyper-inflation in China, 1937-40. Journal of Political Economy, $62,237-245$.

Corcoran, W. J., \& Karels, G. V. (1985). Rent-seeking behavior in the long run. Public Choice, 46, $227-246$.

Downs, A. (1957). An economic theory of democracy. New York: Harper \& Row.

Durden, G. C., Ellis, L. V., \& Millsap, S. W. (1991). Gordon Tullock: His journal and his scholarship. Public Choice, 71, 171-196.

Grier, K. B., \& Tullock, G. (1989). An empirical analysis of cross-national economic growth. Journal of Monetary Economics, 24, 259-276. 
Higgins, R. S., Shughart, W. F, I. I., \& Tollison, R. D. (1985). Free entry and efficient rent seeking. Public Choice, 47, 247-258.

Hill, J. S. (1985). Why so much stability? The impact of agency determined stability. Public Choice, 46, 275-287.

Kruerger, A. O. (1974). The political economy of the rent-seeking society. American Economic Review, 64, 291-303.

Morris, W. (Ed.). (1967). The American heritage dictionary of the English language. New York: American Heritage Publishing Co.

Mueller, D. C. (1993). The 'Virginia School' and public choice. In D. C. Mueller (Ed.), The public choice approach to politics (pp. 431-442). Aldershot: Edward Elgar Publishing Limited.

Mueller, D. C. (2003). Public choice III. Cambridge: Cambridge University Press.

Niemi, R. G. (1983). Why so much stability? Another opinion. Public Choice, 41, 261-270.

Olson, M, Jr. (1965). The logic of collective action. New Haven, CN: Yale University Press.

Olson, M, Jr. (1982). The rise and decline of nations: Economic growth, stagflation and social rigidities. New Haven, CN: Yale University Press.

Stratmann, T. (1996). Instability of collective decisions? Testing for cyclical majorities. Public Choice, $88,15-96$.

Tideman, T. Niclaus, \& Tullock, G. (1976). A new and superior process for making social choices. Journal of Political Economy, 76, 1145-1159.

Tullock, G. (1959). Some problems of majority voting. Journal of Political Economy, 67, 571-79, reprinted in K. J. Arrow, T. Scitovsky (1969), pp. 169-178.

Tullock, G. (1965). The politics of bureaucracy. Washington, DC: Public Affairs Press.

Tullock, G. (Ed.). (1966). Papers on non-market decision making. Charlottesville, VA: Thomas Jefferson Center for Political Economy.

Tullock, G. (1967a). Toward a mathematics of politics. Ann Arbor, MI: University of Michigan Press.

Tullock, G. (1967b). The general irrelevance of the general impossibility theorem. Quarterly Journal of Economics, 81, 256-270.

Tullock, G. (1967c). The welfare costs of tariffs, monopolies and theft. Western Economic Journal, 5, 224-232.

Tullock, G. (1971). The paradox of revolution. Public Choice, 11, 89-100.

Tullock, G. (1976). The vote motive. London: Institute for Economic Affairs.

Tullock, G. (1980a). Trials on trial: The pure theory of legal procedure. New York: Columbia University Press.

Tullock, G. (1980b). Efficient rent seeking. In J. M. Buchanan, R. D. Tollison, \& G. Tullock (Eds.), Toward a theory of the rent-seeking society (pp. 97-112). College Station, TX: Texas A\&M Press.

Tullock, G. (1981). Why so much stability? Public Choice, 37, 189-205.

Tullock, G. (1985). Back to the bog? Public Choice, 46, 259-263.

Tullock, G. (1987). Autocracy. Dordrecht: Kluwer Academic Publishers.

Tullock, G. (1989). The economics of special privilege and rent seeking. Dordrecht: Kluwer Academic Publishers.

Tullock, G. (1993). Rent seeking. London: Edward Elgar Publishing.

Tullock, G. (2003). The origin rent seeking (sic). International Journal of Business and Economics, 2, $1-8$. 